\title{
Coral-dwelling fishes resistant to bleaching but not to mortality of host corals
}

\author{
Mary C. Bonin ${ }^{1,2,}$, Philip L. Munday ${ }^{1,2}$, Mark I. McCormick $^{1,2}$, Maya Srinivasan², \\ Geoffrey P. Jones ${ }^{1,2}$
}

${ }^{1}$ ARC Centre of Excellence for Coral Reef Studies, and ${ }^{2}$ School of Marine and Tropical Biology, James Cook University, Townsville, Queensland 4811, Australia

\begin{abstract}
Coral bleaching is becoming an increasingly common disturbance on coral reefs, and although corals can remain bleached for months prior to recovery or death, little is known about how bleaching affects the associated fish community. The present study reports on recruitment and persistence of coral-dwelling fishes during a natural coral bleaching event in Kimbe Bay, Papua New Guinea. Transect surveys revealed that up to $80 \%$ of branching coral habitats were affected by bleaching. Healthy (i.e. unbleached), severely bleached, and dying colonies of corymbose Acropora spp. were tagged along the reef crest, and resident fish communities were monitored over time. There was no difference in the number of Pomacentrus moluccensis that settled on healthy versus bleached corals. Furthermore, the mean number of $P$. moluccensis recruits remaining on healthy and bleached corals did not differ after $4 \mathrm{wk}$. In contrast, the number of recruits remaining on dead colonies was lower after $4 \mathrm{wk}$ and the frequency of recruit retention was significantly lower on dead colonies compared to healthy or bleached colonies. Similarly, the abundance of coral-dwelling gobies living on healthy or bleached corals did not decrease significantly over $8 \mathrm{wk}$, but all gobies disappeared from corals that died from bleaching. These results suggest that $P$. moluccensis recruits do not avoid bleached corals at settlement and that subsequent survival and/or movement of both recruits and adult coral-dwelling gobies is not negatively influenced, provided that the host coral remains alive. However, it is clear that if corals die from bleaching, coral-specialised fishes will quickly disappear, even prior to structural erosion of the habitat.
\end{abstract}

KEY WORDS: Habitat degradation ' Recruitment $\cdot$ Coral bleaching $\cdot$ Disturbance $\cdot$ Resistance Habitat specialisation · Climate change

Resale or republication not permitted without written consent of the publisher

\section{INTRODUCTION}

Disturbance plays an important role in determining the structure and dynamics of ecological communities (Sousa 1984, Pickett \& White 1985). Although moderate disturbances can promote species diversity by reducing the impact of competitive dominants, severe disturbances invariably have a negative impact on the majority of species. On coral reefs, both physical (e.g. storms) and biological (e.g. crown-of-thorns starfish, coral bleaching, coral disease) disturbances can dramatically impact on coral reef habitat and associated organisms (Karlson \& Hurd 1993, Aronson \& Precht 1995, Jones \& Syms 1998, Jones et al. 2004, Wilson et al. 2006). Although physical disturbances that break down reef structure generally have the most severe impacts on the associated animal communities (Graham et al. 2006), biological disturbances that affect only living coral tissue can be equally detrimental for some groups of animals (Wilson et al. 2006). Species may be resistant to or recover from some disturbances, but the point at which disturbances become intolerable is not well understood. Mass coral-bleaching, caused primarily by elevated sea-surface temperatures as a 
result of climate change, is one of the most critical disturbances that coral reef ecosystems currently face (Hoegh-Guldberg 1999, Wilkinson 2004). When corals are exposed to temperatures 1 to $2^{\circ} \mathrm{C}$ above their average maximum for several consecutive days, they become stressed and expel their symbiotic dinoflagellates (their main source of energy and pigmentation). Heat-stressed corals can either recover or die from bleaching, although corals that recover may suffer from reduced growth, fitness and physiological condition (Jokiel \& Coles 1977, Baird \& Marshall 2002). Differing susceptibilities to bleaching among corals can then lead to dramatic shifts in the structure of coral communities. In a recurring pattern, the branching corals that provide greatest habitat structure for other organisms are often replaced by less structurally complex massive and encrusting growth forms (Marshall \& Baird 2000, Loya et al. 2001, McClanahan et al. 2007).

Coral decline due to bleaching can have far-reaching and detrimental consequences for organisms that rely on corals for food, shelter or living space (Pratchett et al. 2008, 2009). To date most studies have documented the impact of coral mortality caused by bleaching on associated animal communities (e.g. Lindahl et al. 2001, Booth \& Beretta 2002, Spalding \& Jarvis 2002, Garpe et al. 2006). Information about the effects of bleaching per se is very limited. Given that bleaching is becoming a chronic disturbance during which corals can remain bleached for months prior to recovery or death (e.g. Baird \& Marshall 2002), it is crucial to understand how bleaching itself influences basic demographic processes of coral-associated organisms.

Although sparse, the available evidence suggests that the effects of bleaching on animals that depend on live corals for food and shelter can be significant. Symbiotic coral crabs of the genus Trapezia suffer reduced abundance and physiological condition when living and feeding on bleached host corals compared to crabs living and feeding on healthy host colonies (Glynn et al. 1985, Iglesias-Prieto et al. 2003). Although very little is known about the influence of bleaching on animals that use corals primarily for shelter rather than nutrition, the significant declines in abundance of coral-dwelling species shortly after bleaching, and prior to habitat erosion, suggests that habitat bleaching may also have rapid effects on persistence (Lindahl et al. 2001, Bellwood et al. 2006). For example, in surveys conducted immediately after the 1998 bleaching event on the Great Barrier Reef, when some corals were still bleached, Bellwood et al. (2006) found that the abundance of coral-dwelling damselfishes and gobies had already declined significantly. However, it is generally unclear if these declines in abundance occur as a result of bleaching itself or subsequent coral mortality. This information is critical to understand the level of resistance to and potential recovery from bleaching episodes of different intensity. For coraldwelling fishes, healthy coral tissue often appears to be just as important a component of the habitat as structural complexity (Booth \& Beretta 2002, Wilson et al. 2006, Feary et al. 2007a), and bleaching itself may prompt resident fishes to vacate affected host corals in search of undisturbed habitat.

The effects of bleaching may also extend beyond species with an obligate relationship to live coral by influencing settlement and early post-settlement survival of a wide range of species. Many reef fish species use live coral as settlement habitat (Jones et al. 2004, Garpe \& Öhman 2007), and although it is clear that settlers can distinguish between live and dead coral (Öhman et al. 1998, Feary et al. 2007b), it is currently unknown if they avoid settling onto bleached corals. Reef fish use visual and chemical cues to recognise their settlement habitat (Booth 1992, Elliott et al. 1995) and the loss of pigmentation and physiological stress corals experience during bleaching could potentially disrupt these cues. If this is the case, bleaching could have significant and persistent effects on population replenishment, particularly in locations where seasonal recruitment peaks coincide with periods of increased risk of bleaching (e.g. the Great Barrier Reef). Moreover, if recruits do settle onto bleached corals, the pigment loss associated with bleaching could further increase their already high vulnerability to predation. Healthy live coral tissue is thought to help camouflage resident fishes (Wilson et al. 2006), and bleaching could make recruits more visually conspicuous to predators.

The present study was conducted during a natural coral bleaching event in Kimbe Bay, Papua New Guinea and is the first to investigate the immediate effects of bleaching per se on coral reef fish recruitment and persistence. We began by documenting the extent of bleaching at the study site and then used in situ monitoring of fishes living on host colonies across a range of bleaching degradation categories to quantify the immediate effects of this biological disturbance on recruitment and persistence of coral-associated fishes. Like trapezid crabs, coral-dwelling gobies of the genus Gobiodon are live-coral symbionts, and their high degree of live-coral dependence and site fidelity make them ideal candidates for in situ study. The 2 species monitored here, G. histrio and G. quinquestrigatus, occur in only a small suite of corymbose Acropora spp. in Kimbe Bay (Munday 2000). Once breeding pairs are established, Gobiodon spp. may spend their entire lives within the branches of their home coral colony (Wall \& Herler 2008). Similarly, the lemon damselfish Pomacentrus moluccensis is well-suited to study the effects of bleaching on recruitment because it 
exhibits a strong preference for live coral at settlement (Öhman et al. 1998), recruits directly into adult habitat (Brunton \& Booth 2003) and is highly site-attached, with tagging studies showing little movement on contiguous reef environments (Beukers et al. 1995). The specific questions we examined were: (1) How does host-colony bleaching and mortality influence persistence of adult resident gobies? (2) Do settlement-stage P. moluccensis avoid settling onto bleached corals? (3) How does host-colony bleaching and mortality influence the post-settlement persistence of recruits?

\section{MATERIALS AND METHODS}

Study site. The present study was conducted from April to June 2008 during a natural coral bleaching event in Kimbe Bay. The first reports of bleaching in the area in 2008 were at the end of March (V. Messmer pers. comm.) so the study period encompassed the majority of the coral bleaching, recovery and mortality that occurred during the event. The study took place on the exposed side of Garbuna Reef, a large platform reef approximately $1 \mathrm{~km}$ from shore.

Extent of bleaching to branching coral habitats. To determine the extent of bleaching of branching corals, 4 replicate $50 \mathrm{~m}$ line-intercept transects were deployed and benthic substratum was identified under 100 random points along each transect. Surveys were conducted along the reef flat, crest, upper slope and lower slope $(0,2,6$ and $10 \mathrm{~m}$ respectively) to document differences in the extent of bleaching across these depthstratified habitats. Live corals were identified to genus and growth form and were categorised as either healthy (e.g. normal pigmentation) or affected by bleaching.

Effect of coral bleaching and mortality on adult goby persistence. To determine how host-colony bleaching affected the persistence of coral-dwelling gobies, 25 healthy and 20 severely bleached colonies of Acropora nasuta that hosted breeding pairs of either Gobiodon histrio or G. quinquestrigatus were tagged and monitored for $7 \mathrm{wk}$. A. nasuta was chosen because it is a preferred host coral for both gobies (Munday 2000) and is abundant at the study site. In order to categorise host-colony bleaching degradation we used a 4-point scale similar to that developed by Marshall \& Baird (2000): (1) healthy = no visible loss of colour, (2) moderately bleached $=1$ to $50 \%$ of colony affected or entire colony pale, (3) severely bleached $=51$ to $100 \%$ of colony with strong pigmentation loss (colony appears white), (4) dead $=80$ to $100 \%$ of colony covered by light algal overgrowth. Only host colonies that were categorised as severely bleached at the initial inspection were tagged for inclusion in the study. At each subsequent census, colony inter-branch spaces were searched using an underwater torch to identify and count remaining gobies. Bleaching severity of the host colony was then scored using the 4-point scale and proportional mortality was estimated to the nearest $5 \%$ in order to monitor progress in the recovery or death of each colony over time.

Effect of coral bleaching on settlement of Pomacentrus moluccensis. Prior to the new-moon settlement pulse in May 2008, 20 healthy and 19 severely bleached colonies of corymbose Acropora were tagged along the reef crest. Because the presence of conspecifics is a known settlement cue for P. moluccensis (Öhman et al. 1998), at least one older recruit was present on all of the tagged colonies. Colonies were then monitored weekly for $5 \mathrm{wk}$ to track changes in recruit abundance and coral health over time. At each census, the number of $P$. moluccensis recruits was counted, the degree of bleaching severity of the host coral was scored and proportional mortality estimated. Small body size and pale coloration of the new settlers allowed them to be clearly distinguishable from older recruits on the colonies.

Effect of coral bleaching and mortality on postsettlement persistence of recruits. In the first few days following the settlement pulse, the reef crest was again searched for corymbose Acropora colonies in various stages of health that hosted newly settled Pomacentrus moluccensis. A total of 67 coral colonies were located and tagged: 30 healthy, 22 severely bleached and 15 dead colonies. Colonies categorised as severely bleached at the initial census appeared very white with little to no pigmentation, and colonies categorised as dead had between 80 and 100\% mortality at the time of tagging (Fig. 1). Weekly monitoring of each colony was then conducted to document the response of the colony to bleaching and associated changes in the number of $P$. moluccensis recruits remaining. Percent mortality of the host coral was also estimated to the nearest $5 \%$.

Data analysis. Data from the coral-bleaching surveys was averaged across transects at each depth to estimate the proportion of branching corals affected by bleaching and a 1-way ANOVA was used to compare the extent of bleaching between depths. For the goby persistence, Pomacentrus moluccensis settlement, and recruit persistence studies, 1-way ANOVA was used on each data set to compare the density of fish remaining on host corals in each degradation category at the end of the study. Type III sums of squares was used to account for unequal sample sizes and residual analyses were conducted to ensure data conformed to ANOVA assumptions. No data transformations were necessary. When ANOVA produced significant results, Tukey's honestly significant difference (HSD) post hoc 

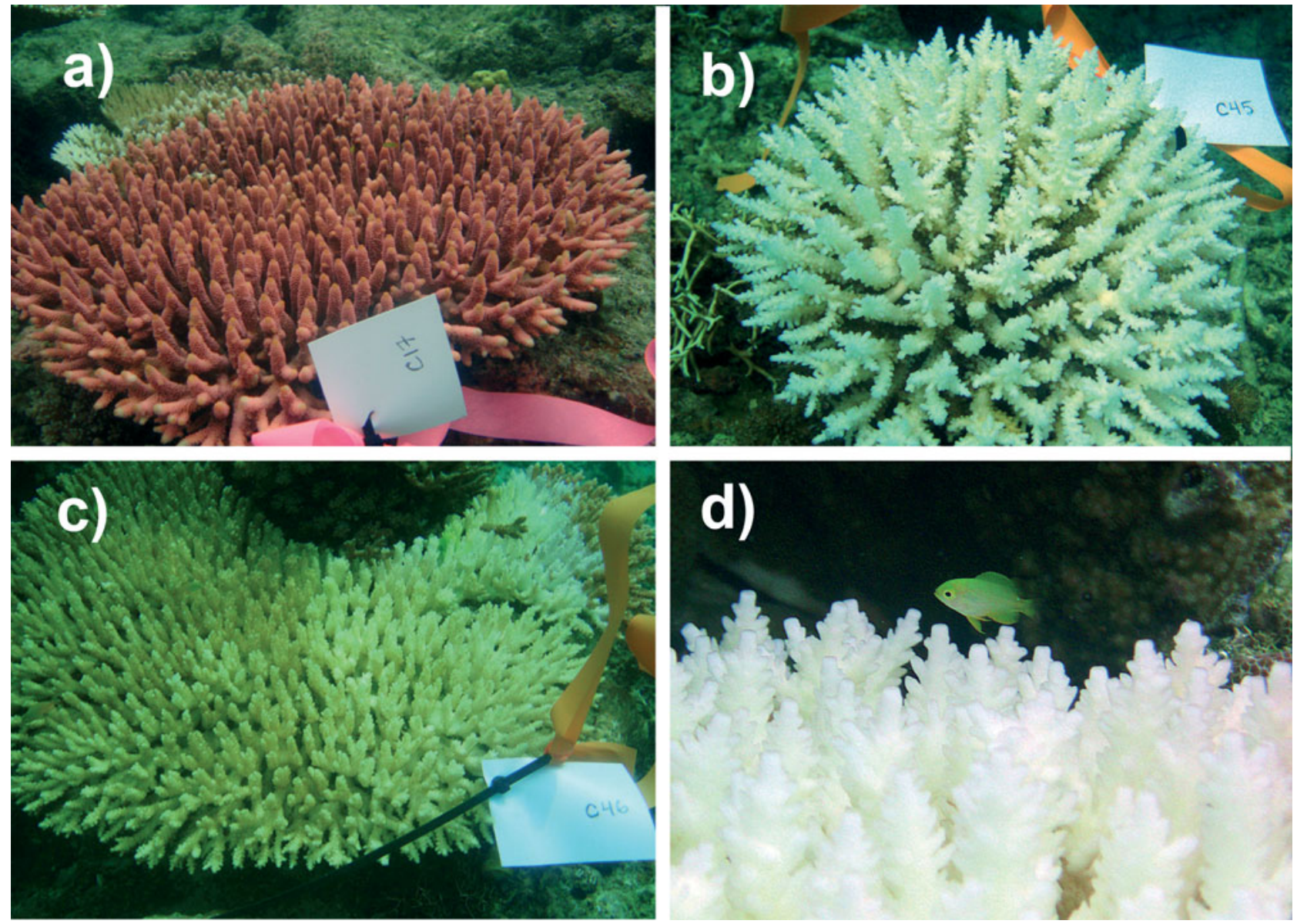

Fig. 1. Colonies of corymbose Acropora spp. were monitored over time to compare recruitment and persistence of coral-dwelling fishes on hosts that were (a) healthy, (b) severely bleached or (c) dead. (d) Living on bleached corals could make coral reef fish recruits more visually conspicuous to predators

tests were used to determine which means differed. In addition, 1-tailed Fisher's exact tests were used to compare the frequency of recruit retention between healthy, bleached and dead colonies after 4 wk.

\section{RESULTS}

\section{Extent of bleaching to branching coral habitats}

The branching coral community covered $\sim 25 \%$ of the benthos and was dominated by corals from the genus Acropora. Mean cover of branching corals did not differ significantly between depths (ANOVA: $\left.F_{3,12}=0.179, \mathrm{p}=0.909\right)$, although the proportion of these corals affected by bleaching decreased significantly with increasing depth (Fig. 2 ; ANOVA: $F_{3,12}=$ $6.977, \mathrm{p}=0.006$ ). On the reef flat $\sim 80 \%$ of branching corals were bleached, compared to $23 \%$ on the lower reef slope.

\section{Effect of coral bleaching and mortality on adult goby persistence}

The 25 healthy colonies of Acropora nasuta that hosted coral gobies remained healthy with no bleaching or mortality during the 7 wk study, whereas the 20 severely bleached hosts either showed signs of recovery $(n=16)$ or died $(n=4)$. There were significant differences in the density of gobies remaining in healthy, bleached and dead host corals after 7 wk (ANOVA: $F_{2,42}=16.702$, $\mathrm{p}<0.001$ ). Although the mean density of gobies on bleached corals tended to be slightly lower than on healthy corals (Fig. 3), a Tukey's HSD test revealed that this difference was not significant. However, goby density was significantly lower on dead corals after $7 \mathrm{wk}$ compared to both healthy and bleached corals. On healthy and bleached host colonies, $\sim 2$ fish remained in each colony throughout the study, whereas goby abundance on dying colonies declined moderately during the first month and then dropped sharply so that 


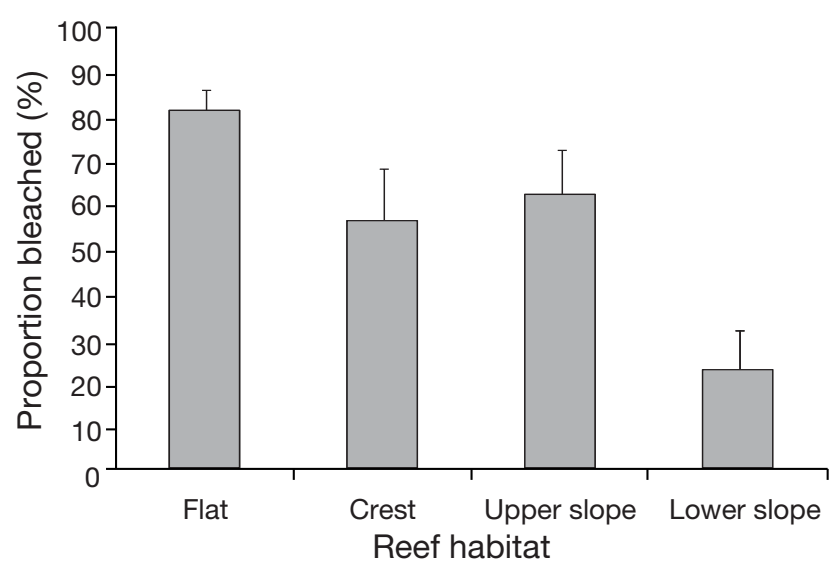

Fig. 2. Acropora spp. Mean proportion of branching corals affected by bleaching along a depth gradient. Error bars are $+\mathrm{SE}$

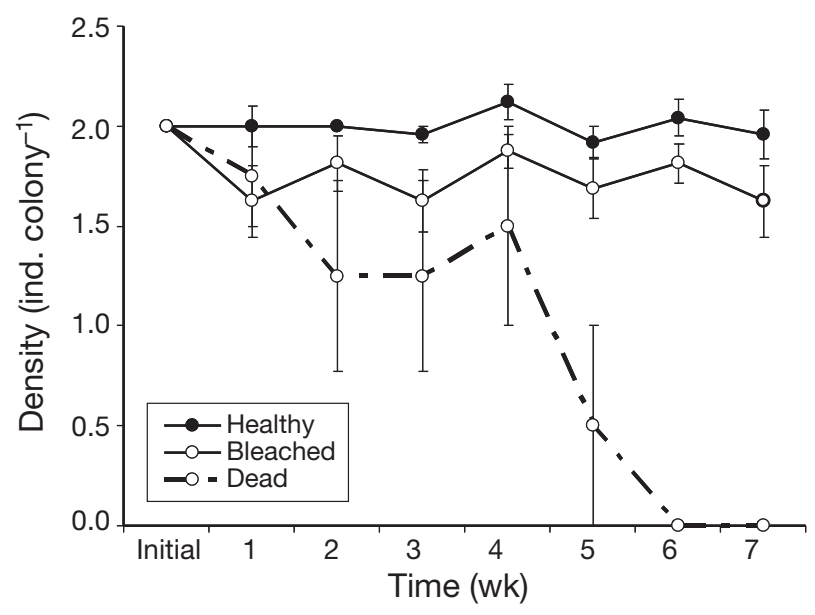

Fig. 3. Gobies on Acropora nasuta. Persistence of coraldwelling gobies living on healthy $(n=25)$, severely bleached $(n=16)$ or dead $(n=4)$ colonies of coral over $7 \mathrm{wk}$. Colonies initially hosted pairs of either Gobiodon histro or G. quinquestrigatus. Error bars are $\pm \mathrm{SE}$

at the end of the study no gobies remained on colonies that died from bleaching (Fig. 3).

\section{Effect of coral bleaching on settlement of Pomacentrus moluccensis}

There was no difference in the number of Pomacentrus moluccensis settling on healthy and severely bleached coral colonies (ANOVA: $F_{1,37}=0.350, \mathrm{p}=$ 0.558). During a settlement pulse, both healthy and bleached host corals received an average of 4 to 5 settlers per coral, and persistence of these settlers did not differ between healthy and bleached colonies over the next month (Fig. 4).

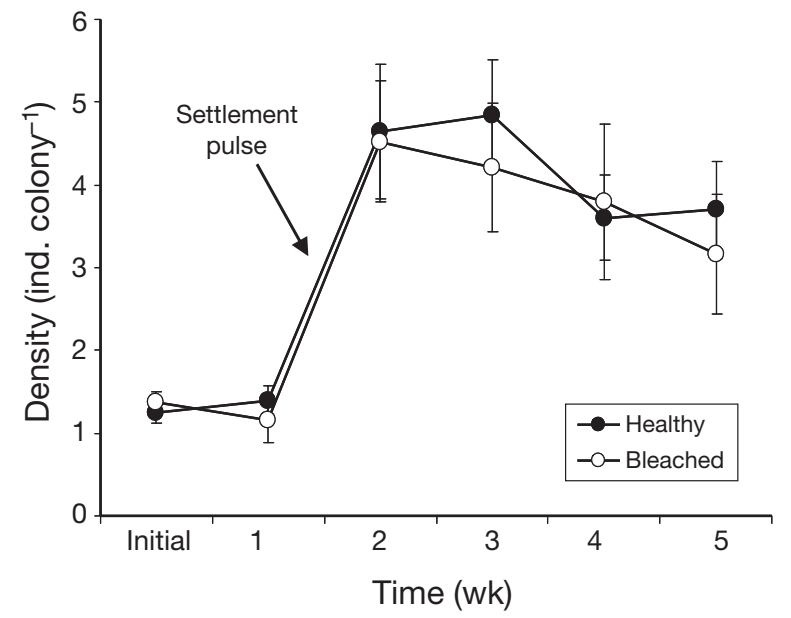

Fig. 4. Pomacentrus moluccensis on Acropora spp. Settlement of lemon damselfish on healthy $(n=20)$ host or severely bleached $(n=19)$ colonies of corymbose coral. Error bars are $\pm \mathrm{SE}$

\section{Effect of coral bleaching and mortality on post- settlement persistence of recruits}

All healthy colonies remained unbleached with no partial mortality throughout the 4 wk study and all the colonies categorised as dead had lost $100 \%$ of their live tissue by the time of the second census. The bleached colonies remained bleached throughout the study, although most showed signs of recovery by the end of the fourth week. These bleached host colonies had a low incidence of partial mortality, with only 3 colonies experiencing 15 to $30 \%$ tissue loss. The abundance of Pomacentrus moluccensis recruits declined steadily over time on host corals in all 3 degradation categories and consequently there was no significant difference in the mean density of recruits remaining on healthy, bleached or dead corals after 4 wk (ANOVA: $F_{3,64}=$ 2.25, $\mathrm{p}=0.113$ ). However, significantly fewer dead colonies retained recruits compared to bleached (Fisher's exact: $\mathrm{p}=0.043$ ) and healthy (Fisher's exact: $\mathrm{p}=0.024$ ) colonies, although there was no difference in recruit retention between bleached and healthy colonies (Fisher's exact: $\mathrm{p}=0.423$ ). Only 2 of the 15 dead colonies had recruits after $3 \mathrm{wk}$ and abundance on those 2 colonies continued to decline during the fourth week. In contrast, recruits persisted to the end of the study on approximately half of both bleached ( $\mathrm{n}=$ $22)$ and healthy $(n=30)$ colonies and declines in abundance on these colonies appeared to stabilise by the third week (Fig. 5). Although recruits of other species did settle on some of the experimental corals during the study, the presence of these recruits was rare compared to the numerically dominant $P$. moluccensis recruits, and therefore assumed not to strongly influence the persistence patterns observed. 


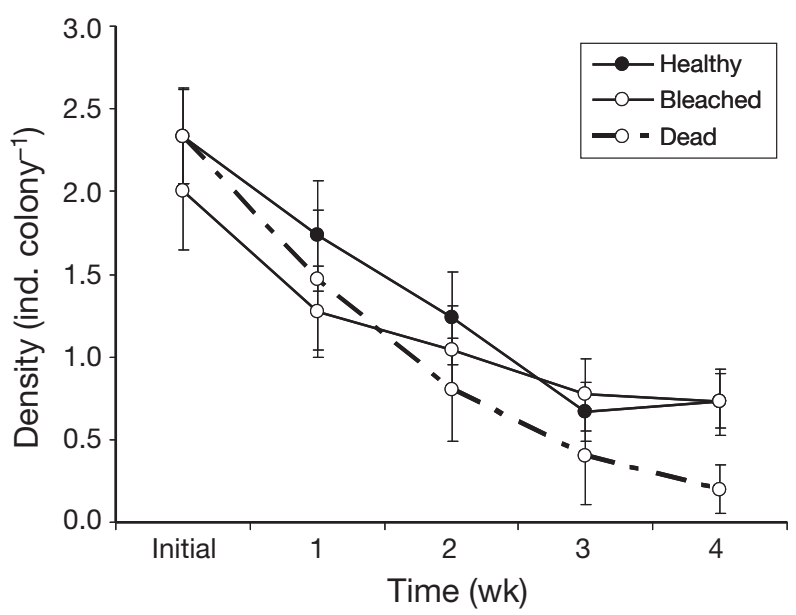

Fig. 5. Pomacentrus moluccensis on Acropora spp. Persistence of lemon damselfish recruits on healthy $(\mathrm{n}=30)$, bleached $(n=22)$ or dead $(n=15)$ host colonies of corymbose coral over $4 \mathrm{wk}$. Error bars are $\pm \mathrm{SE}$

\section{DISCUSSION}

Despite the increasing prevalence of coral bleaching on reefs worldwide, the present study is one of the first to directly examine the effects of bleaching on the associated fish community. This was possible because we monitored fish settlement patterns and abundance during a natural bleaching event. Our results suggest that recruitment and persistence of specialised coraldwelling fishes is resistant to this level of disturbance, provided it does not progress to coral death. Habitat bleaching in itself did not negatively affect settlement patterns or post-settlement survival of recruits and had minimal effects on persistence of adult resident fishes. In contrast, host-colony mortality ultimately led to lower abundance of recruits and caused all adult fish to disappear from their host colonies.

Although several monitoring studies have documented significant declines in the abundance of coraldwelling fishes shortly after bleaching (e.g. Lindahl et al. 2001, Bellwood et al. 2006), it was previously unclear at what stage between bleaching and coral mortality these effects occurred. The results of the present study indicate that bleaching itself is not likely to be the cause of these declines and if corals bleach and recover it should have minimal effects on numerical processes (e.g. recruitment, mortality and movement) in the associated reef fish community. However, if corals suffer widespread mortality following bleaching the loss of live coral tissue will have rapid negative effects on persistence of both recruit and adult coral associated fishes. These effects of live tissue loss were evident well before the structural erosion of the habitat, providing further support for an emerging view that live coral tissue itself is an important resource for many coral-specialised reef fishes (Booth \& Beretta 2002, Wilson et al. 2006, Feary et al. 2007b, Holbrook et al. 2008).

The similarity in the number of Pomacentrus moluccensis settlers arriving at healthy and severely bleached corals indicates that bleaching does not disrupt settlement cues. Although P. moluccensis demonstrate a strong preference for live coral as settlement habitat and avoid settling into dead, algal-covered colonies (Öhman et al. 1998), settlers did not avoid corals that showed signs of stress due to bleaching. After settlement, declines in abundance of recruits on all colony types was expected because predation mortality at this life-history stage is exceptionally high (Almany \& Webster 2006). Less expected was that the persistence trajectories of $P$. moluccensis recruits living on healthy and severely bleached colonies would be so similar. In order to explain why live coral tissue is such an important resource for reef fishes, Wilson et al. (2006) hypothesised that coral tissue may provide camouflage to fish living in close association to corals. If this is the case, bleaching would remove this attribute of the habitat and make recruits more conspicuous to predators. The present study provided a first test of that prediction under natural conditions, and the very similar persistence of recruits on both healthy colourful host corals and those with bleached white tissue suggests that pigmentation of host corals does not affect overall survival of recruits, at least for $P$. moluccensis. However, there could be more subtle effects of this type of habitat change, such as changes to predator and recruit behaviour in association with bleached corals, which warrant future study.

Settlement is a major population bottleneck in coralreef fish communities and the widespread reliance on live coral as settlement habitat makes these communities particularly vulnerable to disturbances that affect live coral (Jones et al. 2004, Wilson et al. 2008). However, the observation that settlement and early postsettlement survival is not negatively affected by habitat bleaching lends support to emerging evidence that replenishment of coral-reef fish communities is resistant to at least the early stages of coral degradation. The species richness of fish colonising experimental plots in Moorea was largely resistant to changes in coral cover and only declined sharply when the cover of live coral was $<10 \%$ (Holbrook et al. 2008). Similarly, in laboratory choice experiments, Feary et al. (2007b) found that many settlement-stage reef fish, including Pomacentrus moluccensis, would settle into both healthy live corals and those degraded by up to $75 \%$ partial mortality. However, even fish that associate with dead habitats as adults avoided settling into totally dead, algal-covered colonies (Feary et al. 
2007b). Furthermore, in the present study, significantly fewer dead colonies retained recruits compared with those that did not bleach, or bleached but did not die. Consequently, total colony mortality appears to be the tipping point at which the habitat becomes unfavourable to coral-associated fishes.

If dead corals are unsuitable as settlement habitat, why were we able to find some settlers living on dead host corals? It may be that when many corals in an area are bleached and dying, priority effects and competition for the few remaining healthy colonies forces inferior competitors to use degraded habitats. Competition for microhabitats among recent settlers can be intense (Bonin et al. 2009), and early post-settlement survival for Pomacentrus moluccensis decreases with increasing group size on a colony (Brunton \& Booth 2003). Using a less crowded, lower-quality habitat is likely to be a short-term solution to avoid competition when high-quality habitat is in short supply. However, this strategy does not seem to be effective in the long run given the ultimately lower persistence on dead colonies.

The response of adult resident fishes to host coral bleaching and mortality paralleled that of recruits. Goby persistence was largely resistant to habitat degradation from bleaching and partial mortality, with some pairs not vacating severely bleached colonies until 50 to $90 \%$ of the live coral tissue had died. Like recruits, small-bodied gobies face a high risk of predation when moving away from shelter, so migration is only likely over relatively short distances. For both Gobiodon histro and G. quinquestrigatus, successful re-location depends upon suitable coral habitat being within $3 \mathrm{~m}$ of their original host colony (Feary 2007). The risk involved in re-location is further compounded by the fact that if preferred host corals are not available nearby, gobies will be forced to take up residence in alternative habitats where they can suffer substantial reductions in growth and survival (Munday 2001). This high degree of habitat specialisation may help to explain the unwillingness of these live-coral symbionts to vacate host corals even when they suffer substantial degradation. The lack of a bleaching effect on the abundance of coral-dwelling gobies contrasts with the response to host-coral bleaching in another live-coral symbiont, the trapezid crab. These crabs feed primarily on the mucus produced by their host corals, and bleaching to the coral on which they feed will significantly reduce their body condition (Glynn et al. 1985). Perhaps as a result of this strong dependence on coral mucus as a food source, Iglesias-Prieto et al. (2003) observed a decline in the density of Trapezia ferruginea living in bleached corals compared to healthy, unaffected corals during the 1997-1998 El Niño Southern Oscillation (ENSO) event in the southern Gulf of
California. Although the diet of Gobiodon spp. does include coral tissue, they also feed on zooplankton (Patton 1994), and this greater flexibility in diet may allow gobies to persist on bleached host corals when crabs cannot. However, there may be sub-lethal consequences for fishes that inhabit and feed on degraded host colonies, and this is an important area for future research (see Feary et al. 2009).

Although reef fish communities do appear to be resistant to considerable degradation to live coral, the fact that fish will settle into or use degraded patches of suitable habitat should not be taken as a safeguard against predicted changes to coral habitats as a result of climate change. Corals with branching growth forms are highly susceptible to bleaching, and coral communities that suffer recurrent bleaching may lose the structural complexity necessary to support diverse reef fish communities. For species with a strong dependence on live branching coral, adaptation to habitat degradation is unlikely (Munday et al. 2008) and there are already indications that the risk of extinction from habitat loss is real (Munday 2004). Finally, although habitat bleaching does not appear to affect the immediate survival of coral-dwelling fishes, future research is required to determine if there are sub-lethal effects of living in degraded habitats.

Acknowledgements. We thank the Patanga community for supporting this project and C. Crothers for assistance with field work. This work was supported by a grant from Mahonia na Dari Research and Conservation Centre and Walindi Plantation Resort to M.C.B. and an Australian Research Council grant to G.P.J.

\section{LITERATURE CITED}

Almany GR, Webster MS (2006) The predation gauntlet: early post-settlement mortality in reef fishes. Coral Reefs 25:19-22

Aronson RB, Precht WF (1995) Landscape patterns of reef coral diversity: a test of the intermediate disturbance hypothesis. J Exp Mar Biol Ecol 192:1-14

Baird AH, Marshall PA (2002) Mortality, growth and reproduction in scleractinian corals following bleaching on the Great Barrier Reef. Mar Ecol Prog Ser 237:133-141

Bellwood DR, Hoey AS, Ackerman JL, Depczynski M (2006) Coral bleaching, reef fish community phase shifts and the resilience of coral reefs. Glob Change Biol 12:1587-1594

> Beukers JS, Jones GP, Buckley RM (1995) Use of implant microtags for studies on populations of small reef fish. Mar Ecol Prog Ser 125:61-66

Bonin MC, Srinivasan M, Almany GR, Jones GP (2009) Interactive effects of interspecific competition and microhabitat on early post-settlement survival in a coral reef fish. Coral Reefs 28:265-274

> Booth DJ (1992) Larval settlement patterns and preferences by Domino damselfish Dascyllus albisella Gill. J Exp Mar Biol Ecol 155:85-104

Booth DJ, Beretta GA (2002) Changes in a fish assemblage after a coral bleaching event. Mar Ecol Prog Ser 245: $205-212$ 
Brunton BJ, Booth DJ (2003) Density- and size-dependent mortality of a settling coral-reef damselfish (Pomacentrus moluccensis Bleeker). Oecologia 137:377-384

Elliott JK, Elliott JM, Mariscal RN (1995) Host selection, location, and association behaviors of anemonefishes in field settlement experiments. Mar Biol 122:377-389

Feary DA (2007) The influence of resource specialization on the response of reef fish to coral disturbance. Mar Biol 153:153-161

Feary DA, Almany GR, Jones GP, McCormick MI (2007a) Coral degradation and the structure of tropical reef fish communities. Mar Ecol Prog Ser 333:243-248

Feary DA, Almany GR, McCormick MI, Jones GP (2007b) Habitat choice, recruitment and the response of coral reef fishes to coral degradation. Oecologia 153:727-737

Feary DA, McCormick MI, Jones GP (2009) Growth of reef fishes in response to live coral cover. J Exp Mar Biol Ecol 373:45-49

Garpe KC, Öhman MC (2007) Non-random habitat use by coral reef fish recruits in Mafia Island Marine Park, Tanzania. Afr J Mar Sci 29:187-199

Garpe KC, Yahya SAS, Lindahl U, Ohman MC (2006) Longterm effects of the 1998 coral bleaching event on reef fish assemblages. Mar Ecol Prog Ser 315:237-247

Glynn PW, Perez M, Gilchrist SL (1985) Lipid decline in stressed corals and their crustacean symbionts. Biol Bull (Woods Hole) 168:276-284

Graham NAJ, Wilson SK, Jennings S, Polunin NVC, Bijoux JP, Robinson J (2006) Dynamic fragility of oceanic coral reef ecosystems. Proc Natl Acad Sci USA 103:8425-8429

Hoegh-Guldberg O (1999) Climate change, coral bleaching and the future of the world's coral reefs. Mar Freshw Res 50:839-866

Holbrook SJ, Schmitt RJ, Brooks AJ (2008) Resistance and resilience of a coral reef fish community to changes in coral cover. Mar Ecol Prog Ser 371:263-271

Iglesias-Prieto R, Reyes Bonilla H, Riosmena Rodriguez R (2003) Effects of the 1997-1998 ENSO on coral reef communities in the Gulf of California, Mexico. Geofis Int 42:467-471

> Jokiel PL, Coles SL (1977) Effects of temperature on mortality and growth of Hawaiian reef corals. Mar Biol 43:201-208

Jones GP, Syms C (1998) Disturbance, habitat structure and the ecology of fishes on coral reefs. Aust J Ecol 23:287-297

> Jones GP, McCormick MI, Srinivasan M, Eagle JV (2004) Coral decline threatens fish biodiversity in marine reserves. Proc Natl Acad Sci USA 101:8251-8253

Karlson RH, Hurd LE (1993) Disturbance, coral reef communities, and changing ecological paradigms. Coral Reefs 12: $117-125$

Lindahl U, Öhman MC, Schelten CK (2001) The 1997/1998 mass mortality of corals: effects on fish communities on a Tanzanian coral reef. Mar Pollut Bull 42:127-131

Loya Y, Sakai K, Yamazato K, Nakano Y, Sambali H, van Woesik R (2001) Coral bleaching: the winners and the losers. Ecol Lett 4:122-131

Editorial responsibility: Tim McClanahan,

Mombasa, Kenya
Marshall PA, Baird AH (2000) Bleaching of corals on the Great Barrier Reef: differential susceptibilities among taxa. Coral Reefs 19:155-163

> McClanahan TR, Ateweberhan M, Graham NAJ, Wilson SK, Sebastian CR, Guillaume MMM, Bruggemann JH (2007) Western Indian Ocean coral communities: bleaching responses and susceptibility to extinction. Mar Ecol Prog Ser 337:1-13

> Munday PL (2000) Interactions between habitat use and patterns of abundance in coral-dwelling fishes of the genus Gobiodon. Environ Biol Fishes 58:355-369

> Munday PL (2001) Fitness consequences of habitat use and competition among coral-dwelling fishes. Oecologia 128: 585-593

> Munday PL (2004) Habitat loss, resource specialization, and extinction on coral reefs. Glob Change Biol 10:1642-1647

Munday PL, Jones GP, Pratchett MS, Williams AJ (2008) Climate change and the future for coral reef fishes. Fish Fish 9:261-285

Öhman MC, Munday PL, Jones GP, Caley MJ (1998) Settlement strategies and distribution patterns of coral-reef fishes. J Exp Mar Biol Ecol 225:219-238

Patton WK (1994) Distribution and ecology of animals associated with branching corals (Acropora spp.) from the Great Barrier Reef, Australia. Bull Mar Sci 55:193-211

Pickett STA, White PS (eds) (1985) The ecology of natural disturbance and patch dynamics. Academic Press, Orlando, FL

Pratchett MS, Munday PL, Wilson SK, Graham NAJ and others (2008) Effects of climate-induced coral bleaching on coral-reef fishes: ecological and economic consequences. Oceanogr Mar Biol Annu Rev 46:251-296

Pratchett MS, Wilson SK, Graham NAJ, Munday PL, Jones GP, Polunin NVC (2009) Coral bleaching and consequences for motile reef organisms: past, present and uncertain future. In: van Oppen MJH, Lough JM (eds) Coral bleaching: patterns, processes, causes and consequences. Springer, Heidelberg, p 139-158

> Sousa WP (1984) The role of disturbance in natural communities. Annu Rev Ecol Syst 15:353-391

Spalding MD, Jarvis GE (2002) The impact of the 1998 coral mortality on reef fish communities in the Seychelles. Mar Pollut Bull 44:309-321

Wall M, Herler J (2008) Postsettlement movement patterns and homing in a coral-associated fish. Behav Ecol 20: 87-95

Wilkinson CR (2004) Status of coral reefs of the world. Australian Institute of Marine Science, Townsville

Wilson SK, Graham NAJ, Pratchett MS, Jones GP, Polunin NVC (2006) Multiple disturbances and the global degradation of coral reefs: are reef fishes at risk or resilient? Glob Change Biol 12:2220-2234

Wilson SK, Burgess SC, Cheal AJ, Emslie M and others (2008) Habitat utilization by coral reef fish: implications for specialists vs. generalists in a changing environment. J Anim Ecol 77:220-228

Submitted: May 25, 2009; Accepted: August 29, 2009 Proofs received from author(s): November 11, 2009 